\title{
Comparison of the PET Values with the Open Pan Evaporation and Computation of Crop Coefficients
}

\author{
Usha Durgam* and A.S.R.A.S. Sastri \\ Department of Agrometeorology, Indira Gandhi Krishivishwavidyalaya, \\ Raipur-492012 (C.G), India \\ *Corresponding author
}

\section{A B S T R A C T}

\section{Keywords}

Modified Penman.

Crop coefficient,

Regression analysis

Article Info

Accepted:

10 June 2018

Available Online:

10 July 2018
The comparison of ETo estimates was done based on the weekly averages of PET using correlation coefficient and regression methods through different empirical methods namely Modified Penman, Blaney criddle, Christiansen, Thornthwaite, OpenPan, FAO penman method by using daily weather data for the period 1981-2012 (32 years) has collected for three stations of Chhatisgarh state. Atambikapur the highest correlation coefficient between FAO penman and Modified penman method is 0.998 and lowest in between Christiansen and Blaney criddle method is 0.918. At Jagdalpur and Raipur also having the highest correlation coefficient between FAO Penman and Modified Penman method is 0.999 and lowest correlation coefficient $I$ in between Christiansen and Turc method is 0.85 or 0.84 .Regarding regression with open Pan evaporation highest $\mathrm{R}^{2}$ values are Modified penman and Christiansen methods.

\section{Introduction}

Evapotranspiration is a combination of physical and biological processes through which water enters into the atmosphere in the form of water vapour. The term evapotranspiration is used to describe the total process of water transfer into the atmosphere from vegetation and land surfaces. Evapotranspiration depends upon the availability of water, temperature and humidity of the air, wind movement and velocity and duration of sunshine. In tropical countries like India, abundance or scarcity of moisture has a great influence on plant growth. Rainfall is the main source for moisture supply to plants. When the crop is small, water is predominantly lost by evaporation from the soil surface, but once the crop is well developed and completely covers the soil, transpiration becomes the main process (Allen et al., 1996). Estimates of evapotranspiration provide an outlook of soil water balance is association with the amount of precipitation. Such estimates are of immense importance for the calculation of water demand of the field crops and irrigation Scheduling (Rasul 1992). Potential evapotranspiration is usually measured indirectly from other climatic factors but also depends on the surface type such as free water (for lakes and oceans) the soil type for bare 
soil, and the vegetation.ET is useful to determine how much water has evaporated from the cropped field.

The Penman -Monteith equation presented by Food and Agriculture Organisation as the standard method to estimate ET and hence they used common methods i.e. Modified Penman, Blaneycriddle and FAO Radiation methods for inter comparison based on the least root mean square and regression analysis (Meshram et al., 2010)

\section{Materials and Methods}

The studies was conducted at the Instructional Farm, Indira Gandhi Agricultural University, Raipur revealed that the significance of weather parameters that influence evapotranspiration (ET) varied from year to year. Looking into this it has been hypothesized that the weather parameters influence the ET if the parameter fluctuates above and below the optimum values. In order to study the ET estimation by different methods in Raipur station, the historical weather data was collected from Department of Agrometeorology, Indira Gandhi Agricultural University, Raipur. At Ambikapur station the PET is lowest in winter months and highest in summer months. The relationship between open pan evaporation and PET values by different methods at Ambikapur showed that the regression coefficients for all the methods of PET estimation with open pan evaporation values are very high except in Turc and Blaney Criddle methods. From the regression equations the lowest $\mathrm{R}^{2}$ value was in respect of Turc method (0.78) followed by Blaney Criddle method (0.88). In case of Raipur the relationship between open pan evaporation and Christiansen method of estimation of PET is highest with $\mathrm{R}^{2}$ values of 0.99 followed by Modified Penman method of PET estimation.
Relation between weather parameters and PET by different methods at Ambikapur showed that the relative humidity values are negatively correlated with different methods of estimation of PET while maximum temperature, minimum temperature and wind speed are positively correlated. The maximum temperature is highly correlated with different methods of estimation of PET as compared to minimum temperature though both are significantly correlated at $1 \%$ level In Jagdalpur station as was observed at Ambikapur, the correlation values between maximum temperature and PET values computed by different methods are very high correlated as compared to minimum temperature.

In Raipur, unlike at Ambikapur and Jagdalpur maximum temperature is highly correlated with pan evaporation values in all methods of estimation of PET. The correlation coefficient values with maximum temperature varied from 0.91 with respect to Turc method to 0.99for Modified Penman and FAO Penman methods.

\section{Penman's method}

The potential evapotranspiration which is the maximum amount of evaporation from soil and transpiration from vegetation that takes place over an extensive area with adequate moisture at all times, was computed by Penman's (1948) equation as given below:

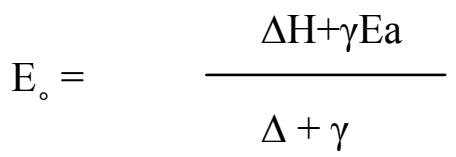

where,

$\Delta=$ Slope of the saturated vapour pressure curve at temperature. $\mathrm{T}^{\circ} \mathrm{C}$

$\gamma=$ Psychrometric constant (0.49)

$\mathrm{H}=$ Energy balance term 
$=\mathrm{RA}(1-\alpha)(0.18+0.55) \mathrm{n} / \mathrm{N})-\sigma \mathrm{Ta}^{4}(0.55-$ 0.092 Ved $)(0.10+0.90 \mathrm{n} / \mathrm{N})$

where,

$\mathrm{RA}=$ Extra terrestrial radiation $(\mathrm{mm}$ of water/day)

$\alpha \quad=$ Albedo which is assumed as 0.25

$\mathrm{n} \quad=$ Actual bright sunshine hours

$\mathrm{N} \quad=$ Possible bright sunshine hours

$\sigma \quad=$ Stephen Bottzman constant $=0.817$ $\mathrm{x} 10-10 \mathrm{cal} / \mathrm{cm}^{2} / \mathrm{mm} /{ }^{\circ} \mathrm{K}^{4}$ later converted to $20.284 \mathrm{~mm} / \mathrm{day} /{ }^{\circ} \mathrm{K}^{4}$

$\mathrm{Ta}=$ Mean air temperature

ed $=$ Actual vapour pressure

$$
\text { ed }=\frac{\text { RH mean } x \text { ea }}{100}
$$

$\mathrm{Ea}=$ Aerodynamic term $=0.35\left(\mathrm{e}_{\mathrm{a}}-\mathrm{e}_{\mathrm{d}}\right)\left(1+0.0098 \mathrm{U}_{2}\right)$

Where,

$\mathrm{e}_{\mathrm{a}}=$ saturated vapour pressure

$\mathrm{U}_{2}=24$ hours total wind run of two meters height in miles

The wind speed, which is measured at 10 feet height, was converted at two meter height using the logarithmic equation as:

$\mathrm{U}_{\mathrm{h} 1} \log \mathrm{h}_{1}=\mathrm{U}_{\mathrm{h} 2} \log \mathrm{h}_{2}$

Therefore, $\mathrm{U}_{\mathrm{h} 2}=\left(\mathrm{U}_{\mathrm{h} 1} \log \mathrm{h}_{1}\right) / \log \mathrm{h}_{2}$

Where,

$\mathrm{U}_{\mathrm{h}}=$ wind run at height ' $\mathrm{h}$ '

\section{Thornthwaite method}

Thornthwaite (1948) considered temperature and day length to estimate the potential evapotranspiration
Thornthwaite's formula for unadjusted PET $(\mathrm{cm} /$ month) is:

UPET $=1.695\left[\frac{10 \mathrm{~T}}{\mathrm{I}}\right]^{\mathrm{T}}$

where

UPET = Unadjusted potential evapotranspiration $\mathrm{T}=$ Mean monthly temperature in ${ }^{\circ} \mathrm{C}$

$\mathrm{I}=$ Annual heat index

$\mathrm{i}=$ monthly heat index $\mathrm{i}=(\mathrm{T} / 5)^{1.514}$

$\mathrm{T}=$ mean monthly temperature $\left({ }^{\circ} \mathrm{C}\right)$

$\mathrm{a}=$ non linear function of heat index approximated by the expression

$$
\begin{gathered}
\mathrm{a}=6.75 \times 10^{-7} \mathrm{I}^{3}-7.71 \times 10^{-5} \mathrm{I}^{2}+1.792 \mathrm{x} \\
10^{-2} \mathrm{I}+0.49239
\end{gathered}
$$

The unadjusted potential evapotranspiration UPET values so obtained are for an average of a 30 day month with 12 hours of day length. The values must be adjusted by multiplying by a correction factor that expresses how each particular month varies. The correction factor for each month in different years was worked out by using the formula.

Correlation Factor=

$\mathrm{N}$ no. of days in month

$\mathrm{X}$

12

30

\section{Blaney-Criddle method}

Blaney-Criddle formula for estimating ETo i.e. reference crop evapotranspiration in $\mathrm{mm}$ /day for the month considered is:

PET $=(0.0173$ Ta-0.314 $)]$ Kc $X \quad$ Ta $X$ $\mathrm{D} / 4465.6$ X25.4 mm/day

Where, 
$\mathrm{Ta}=$ mean air temperature in ${ }^{\circ} \mathrm{F}$

$\mathrm{Kc}=$ Crop Coefficient

$\mathrm{D}=$ Day Length,

\section{Turc method}

Turc gave the following formula for the estimation of daily PET:

$\mathrm{PET}=0.40 \mathrm{Tc}(\mathrm{RI}+50) /(\mathrm{Tc}+15) \mathrm{N}$

Where,

PET=Potential evapotranspiration

$\mathrm{Tc}=$ Mean air temperature, ${ }^{\circ} \mathrm{C}$

$\mathrm{RI}=$ Solar radiation (ly/day)

$\mathrm{N}=\mathrm{NO}$. Of Days in month

\section{Hargreaves method}

$\mathrm{PET}=0.0135(\mathrm{t}+17.78) \mathrm{Rs}$

$\mathrm{PET}=$ Reference crop potential consumptive use,

$\mathrm{t}=$ average daily temperature

Rs=Incident solar radiation ly/day

$\mathrm{Rs}=0.10 \mathrm{Rso}(\mathrm{S}){ }^{1} \mathbf{2}$

$\mathrm{S}=$ Percent of possible sunshine

Rso=Clear day solar radiation in ly day ${ }^{-1}$

\section{Christiansen method}

Christiansen equation for estimation of ETo is presented in a following way: $\mathrm{ETo}=0.755$ Epan. Ct.Cu.Ch.Cs

Where,

$\mathrm{ETo}=$ Reference evapotranspiration $\left(\mathrm{mm} \mathrm{day}^{-1}\right)$ Epan=measured evaporation from class a pan $\left(\mathrm{mm}\right.$ day $\left.^{-1}\right)$ Coefficients are dimensionless

$\mathrm{Ct}=0.862+0.179(\mathrm{~T} / \mathrm{To})-0.041(\mathrm{~T} / \mathrm{To})^{2}$

Where $\mathrm{T}=$ mean temperature in ${ }^{\circ} \mathrm{C}$ and $\mathrm{To}=20^{\circ} \mathrm{C}$ $\mathrm{Cu}=1.189-0.240(\mathrm{U} / \mathrm{Uo})+0.051(\mathrm{U} / \mathrm{Uo})^{2}$ where $\mathrm{U}$ is the mean wind speed at $2 \mathrm{~m}$ height $(\mathrm{km} / \mathrm{hr})$ and $\mathrm{Uo}=6.7 \mathrm{~km} / \mathrm{hr}$

$\mathrm{Ch}=0.499+0.620(\mathrm{H} / \mathrm{Ho})-0.119(\mathrm{H} / \mathrm{Ho})^{2}$

Where $\mathrm{H}=$ mean relative humidity and $\mathrm{Ho}=0.6$

$\mathrm{Cs}=0.904+0.008(\mathrm{~S} / \mathrm{So})+0.088(\mathrm{~S} / \mathrm{So})$

Where S=percentage of Possible sunshine expressed decimally and $\mathrm{So}=0.8$

\section{FAO Penman Monteith equation}

Monteith (1963 and 1964) introduced resistant terms into penman method:

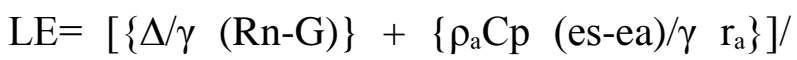
$(\Delta / \gamma+1+\mathrm{rc} / \mathrm{ra})$

Where,

$\rho_{\mathrm{a}}=$ density of air, $1.3 \mathrm{~kg} / \mathrm{m}^{3}$

$\mathrm{Cp}=$ Specific heat of air at constant pressure, $1008 \mathrm{j} / \mathrm{kg} /{ }^{\circ} \mathrm{C}$

$\mathrm{ra}=$ Aerodynamic resistance, $\mathrm{s} / \mathrm{m}$

$\mathrm{rc}=$ canopy resistance, $\mathrm{s} / \mathrm{m}$ and taken as rs +15

rs=stomatal resistance

$\mathrm{rs}=[(\mathrm{rad} \mathrm{xrab}) /(\mathrm{rad}+\mathrm{rab})] / \mathrm{LAI}$

$\mathrm{rab}=$ abaxial resistance

LAI=leaf area index

$\mathrm{rad}=$ adaxial resistance

ea $=$ Actual vapor pressure, $\mathrm{mm}$ of $\mathrm{Hg}$

$\mathrm{Es}=$ saturation vapor pressure, $\mathrm{mm}$ of $\mathrm{Hg}$

Where,

$\mathrm{Z}=$ height

$\mathrm{d}=$ Zero plane displacement $=0.63 \mathrm{z}$

$\mathrm{Zo}=$ Roughness parameter $=0.13 \mathrm{z}$

$\mathrm{r}_{\mathrm{a}}=[\ln \{(\mathrm{z}-\mathrm{d}) / \mathrm{zo}\}]^{2 / \mathrm{uk}^{2},}$ aerodynamic resistance

$\mathrm{U}=$ Wind speed at height, $\mathrm{z}$

$\mathrm{K}=$ Von Karman's constant (.41) 


\section{Open pan evaporation}

The daily value of open pan evaporation were measured by using a U.S.W.B. class A open pan evaporimeter at 0830 and 1430 hours IST in the Agrometeorological Observatory College of Agricultural, Raipur were used.

The data required for the computation of penman, thornthwaite and Blaney-Criddle methods for estimating potential evapotranspiration were collected from the Agrometeorological observatory situated near the experimental site.

\section{Correlation coefficient analysis}

Correlation Coefficient is a measure of degree of extent of linear relationship between two variable $\mathrm{X}$ and $\mathrm{Y}$.

$\mathrm{r}=\operatorname{cov}(\mathrm{XY} / \sigma \mathrm{x} . \sigma \mathrm{y}$

Where,

$\mathrm{r}=$ correlation coefficient

$\operatorname{Cov}(x, y)=1 / n(x-\bar{x})(y-\bar{y})$

\section{Standard deviation}

$\sigma \mathrm{x}=1 / \mathrm{n} \sum(\mathrm{x}-\overline{\mathrm{x}}) 2=$ Standard deviation of $\mathrm{x}$

$\sigma \mathrm{y}=1 / \mathrm{n} \Sigma(\mathrm{y}-\overline{\mathrm{y}}) 2=$ Standard deviation of $\mathrm{y}$

\section{Results and Discussion}

It is seen from the Table 1, that the relation between different methods of estimation of PET is very highly correlated. The correlation coefficient values varied from 0.996 to 0.918 indicating that this 6 methods are well correlated with each other. However at Ambikapur the relationship between Christiansen method of estimation of PET and BlaneyCriddle method is lower than other methods while at Jagdalpur the correlation coefficient among different methods of estimation of PET are relatively less as compared to Ambikapur. The lowest correlation coefficient was between the Christiansen and Hargreaves methods and also between Christiansen and Turc method.

The highest correlation coefficient was found with Open pan and Christiansen method of estimation of PET also the correlation coefficient between Penman Monteith and Modified Penman method are very highly correlated $(\mathrm{C}=0.999)$.

At Raipur also there are strong relationships between the different methods of estimation of PET. The lowest correlation coefficient was between Christiansen and Turc method while FAO Penman Monteith method and Modified Penman methods are very high correlated with correlation coefficient 0.999 .

Regression equations between open pan evaporation and the PET values by different methods

In order to find out the relationship between open pan evaporation and PET values by different methods regression analysis was carried out on weekly basis for different stations. The results are discussed below for each station separately.

\section{Ambikapur}

The relationship between open pan evaporation and PET values by different methods. It can be seen from the figure that regression coefficients for all in the methods of PET estimation with open pan evaporation values are very high except Turc and BlaneyCriddle methods.

The regression equations for Ambikapur station are as follows: 
1) Open Pan and Modified Penman method $\mathrm{Y}=5.6+1.149 \mathrm{X} \quad\left(\mathrm{R}^{2}=0.99\right)$

2) Open Pan and Hargreaves method $\mathrm{Y}=12.9+0.833 \mathrm{X} \quad\left(\mathrm{R}^{2}=0.96\right)$

3) Open Pan and Turc method $\mathrm{Y}=16.64+0.43 \mathrm{X} \quad\left(\mathrm{R}^{2}=0.78\right)$

4) Open Pan and BlaneyCriddle method $\mathrm{Y}=6.69+1.0568 \mathrm{X}\left(\mathrm{R}^{2}=0.88\right)$

5) Open Pan and Christiansen method $\mathrm{Y}=2.97+1.331 \mathrm{X} \quad\left(\mathrm{R}^{2}=0.99\right)$

5) Open Pan and FAO Penman method $\mathrm{Y}=3.79+1.0471 \mathrm{X}\left(\mathrm{R}^{2}=0.99\right)$

Where $X=$ Open Pan values

It can be seen from the regression equation the lowest $\mathrm{R}^{2}$ value was in respect of Turc method (0.78) followed by BlaneyCriddle method (0.88).In case of other methods the relationship with open pan evaporation is very high $\left(\mathrm{R}^{2}=0.99\right)$

\section{Jagdalpur}

The regression equations between open pan evaporation and PET computed by different methods are worked out. The regression equations for different methods of PET with open pan evaporation are shown below:

1) Open Pan and Modified Penman method

$$
\mathrm{Y}=8.80+1.1629 \mathrm{X} \quad\left(\mathrm{R}^{2}=0.83\right)
$$

2) Open Pan and Hargreaves method

$$
\begin{aligned}
& \mathrm{Y}=14.27+1.0749 \mathrm{X}\left(\mathrm{R}^{2}=0.73\right) \\
& \mathrm{Y}=\text { Hargreaves method }
\end{aligned}
$$

3) Open Pan and Turc method

$$
\mathrm{Y}=14.26+0.5718 \mathrm{X} \quad\left(\mathrm{R}^{2}=0.73\right)
$$

4) Open Pan and BlaneyCriddle method

$$
\mathrm{Y}=3.93+1.2345 \mathrm{X} \quad\left(\mathrm{R}^{2}=0.91\right)
$$

5) Open Pan and Christiansen method

$$
\mathrm{Y}=1.876+1.257 \mathrm{X} \quad\left(\mathrm{R}^{2}=0.99\right)
$$

6) Open Pan and FAO Penman method

$$
\mathrm{Y}=7.33+1.043 \mathrm{X}\left(\mathrm{R}^{2}=0.83\right)
$$

Where $\mathrm{X}=$ Open Pan values

At Jagdalpur, the regression coefficients (coefficient of determination)are relatively lower in respect of all the methods. The lowest regression coefficient was in respect of Hargreaves and Turc methods (0.73) while it is highest with BlaneyCriddle method.

\section{Raipur}

In case of Raipur the relationship between open pan evaporation and Christiansen method of estimation of PET is the highest with $\mathrm{R}^{2}$ values of 0.99 followed by Modified Penman method of PET estimation. The relationship between open pan $\mathrm{E}_{0}$ and FAO Penman and Hargreaves methods of estimation of PET are also higher with $\mathrm{R}^{2}$ value of 0.94 .The lowest relationship was found in respect of Turc method of estimation of PET.

1) Open Pan and Modified Penman method $Y=-1.617+13516 X \quad\left(R^{2}=0.95\right)$

2) Open Pan and Hargreaves method $\mathrm{Y}=6.015+1.0647 \mathrm{X}\left(\mathrm{R}^{2}=0.94\right)$

3) Open Pan and Turc method $\mathrm{Y}=10.185+0.6888 \mathrm{X}\left(\mathrm{R}^{2}=0.90\right)$

4) Open Pan and BlaneyCriddle method $\mathrm{Y}=-3.0674+1.3957 \mathrm{X}\left(\mathrm{R}^{2}=0.88\right)$

5) Open Pan and Christiansen method $\mathrm{Y}=3.605+1.2919 \mathrm{X}\left(\mathrm{R}^{2}=0.99\right)$

7) Open Pan and FAO Penman method $\mathrm{Y}=-1.689+1.185 \mathrm{X}\left(\mathrm{R}^{2}=0.94\right)$

Where $\mathrm{X}=$ Open Pan values 
Table.1 Correlation coefficient between PET values under different methods at Ambikapur

\begin{tabular}{|l|l|l|l|l|l|l|l|}
\hline \multicolumn{1}{|c|}{$\begin{array}{c}\text { PET under } \\
\text { different } \\
\text { methods }\end{array}$} & $\begin{array}{l}\text { Modified } \\
\text { Penman }\end{array}$ & $\begin{array}{l}\text { Hargr } \\
\text { eaves }\end{array}$ & Turc & $\begin{array}{l}\text { Blaneyc } \\
\text { riddle }\end{array}$ & $\begin{array}{l}\text { christi } \\
\text { ansen }\end{array}$ & $\begin{array}{l}\text { open } \\
\text { pan }\end{array}$ & $\begin{array}{l}\text { FAO penman } \\
\text { method }\end{array}$ \\
\hline $\begin{array}{l}\text { Modified } \\
\text { Penman }\end{array}$ & 1 & & & & & & \\
\hline Hargreaves & 0.996 & 1 & & & & & \\
\hline Turc & 0.984 & 0.986 & 1 & & & & \\
\hline BlaneyCriddle & 0.952 & 0.949 & 0.951 & 1 & & & \\
\hline Christiansen & 0.973 & 0.966 & 0.943 & 0.918 & 1 & & \\
\hline Open Pan & 0.976 & 0.916 & 0.953 & 0.941 & 0.996 & 1 & \\
\hline $\begin{array}{l}\text { FAO Penman } \\
\text { Method }\end{array}$ & 0.998 & 0.995 & 0.984 & 0.938 & 0.973 & 0.973 & 1 \\
\hline
\end{tabular}

Table.2 Correlation coefficient between PET values under different methods at Jagdalpur

\begin{tabular}{|l|l|l|l|l|l|l|l|}
\hline \multicolumn{1}{|c|}{$\begin{array}{l}\text { PET under } \\
\text { different } \\
\text { methods }\end{array}$} & $\begin{array}{l}\text { Modified } \\
\text { Penman }\end{array}$ & $\begin{array}{l}\text { Hargr } \\
\text { eaves }\end{array}$ & Turc & $\begin{array}{l}\text { Blaney } \\
\text { Criddle }\end{array}$ & $\begin{array}{l}\text { Christi } \\
\text { ansen }\end{array}$ & $\begin{array}{l}\text { Open pan } \\
\text { PET }\end{array}$ & $\begin{array}{l}\text { FAO } \\
\text { Penman } \\
\text { Method }\end{array}$ \\
\hline Modified Penman & 1 & & & & & & \\
\hline Hargreaves & 0.957 & 1 & & & & & \\
\hline Turc & 0.960 & 0.973 & 1 & & & & \\
\hline BlaneyCriddle & 0.931 & 0.938 & 0.927 & 1 & & & \\
\hline Christiansen & 0.921 & 0.850 & 0.850 & 0.941 & 1 & & \\
\hline Open Pan & 0.911 & 0.859 & 0.854 & 0.955 & 0.996 & 1 & \\
\hline $\begin{array}{l}\text { FAO Penman } \\
\text { Method }\end{array}$ & 0.999 & 0.960 & 0.964 & 0.934 & 0.920 & 0.916 & 1 \\
\hline
\end{tabular}

Table.3 Correlation coefficient between PET values under different methods of Raipur

\begin{tabular}{|l|l|l|l|l|l|l|l|}
\hline \multicolumn{1}{|c|}{$\begin{array}{l}\text { PET under } \\
\text { different } \\
\text { methods }\end{array}$} & $\begin{array}{l}\text { Modified } \\
\text { Penman }\end{array}$ & $\begin{array}{l}\text { Hargr } \\
\text { eaves }\end{array}$ & Turc & $\begin{array}{l}\text { Blaney } \\
\text { Criddle }\end{array}$ & $\begin{array}{l}\text { Christi } \\
\text { ansen }\end{array}$ & $\begin{array}{l}\text { Open pan } \\
\text { PET }\end{array}$ & $\begin{array}{l}\text { FAO } \\
\text { Penman } \\
\text { Method }\end{array}$ \\
\hline Modified Penman & \multicolumn{1}{|c|}{1} & & & & & & \\
\hline Hargreaves & 0.986 & 1 & & & & & \\
\hline Turc & 0.902 & 0.914 & 1 & & & & \\
\hline BlaneyCriddle & 0.934 & 0.957 & 0.944 & 1 & & & \\
\hline Christiansen & 0.991 & 0.969 & 0.848 & 0.907 & 1 & & \\
\hline Open pan PET & 0.995 & 0.984 & 0.886 & 0.941 & 0.995 & 1 & \\
\hline $\begin{array}{l}\text { FAO Penman } \\
\text { Method }\end{array}$ & 0.999 & 0.984 & 0.906 & 0.934 & 0.991 & 0.995 & 1 \\
\hline
\end{tabular}


The values of PET under different methods are very highly correlated. The correlation coefficient varies from 0.996 to 0.918 indicating that these 6 methods are correlated with each other. However at Ambikapur the relationship between Christiansen method of estimation of PET and Blaney Criddle method is lower than other methods while at Jagdalpur the correlation coefficient among different methods of estimation of PET are relatively less as compared to Ambikapur. The lowest correlation coefficient was between the Christiansen and Hargreaves and also between Christiansen and Turc methods. At Raipur also there is strong relationship between the different methods of estimation of PET. The lowest correlation coefficient was between Christiansen and Turc methods while FAO Penman Monteith method and Modified Penman method have very high correlation coefficient (0.999) (Table 2 and $3)$.

The relationship between open pan evaporation and PET values by different methods at Ambikapur showed that the regression coefficients for all the methods of PET estimation with open pan evaporation values are very high except Turc and Blaney Criddle methods. From the regression equation the lowest $R^{2}$ value was in respect of Turc method (0.78) followed by Blaney Criddle method (0.88).In case of other methods, the relationship with open pan evaporation is very high $\left(\mathrm{R}^{2}=0.99\right)$.

At Jagdalpur the regression coefficients are relatively lower in respect of all methods. The lowest regression coefficient was in respect of Hargreaves and Turc methods (0.73) while it is highest with Blaney Criddle method.

In case of Raipur the relationship between open pan evaporation and Christiansen method of estimation of PET is highest with $\mathrm{R}^{2}$ values of 0.99 followed by Modified
Penman method of PET estimation. The relationship between open pan and FAO Penman and Hargreaves methods of estimation of PET is also higher with $R^{2}$ value of 0.94. The lowest relationship was found in respect of Turc method of estimation of PET.

\section{Acknowledgement}

I am greatly indebted to Shri. A.S.R.A.S Sastri and My dear collegues, Seniors and all staff of the Department of Agrometeorology of IGKV Raipur for the kind assistance during the period of study.

\section{References}

A Laaboudi, B Mouhouche and B Draoui (2012).Conceptual reference evapotranspiration models for different time steps. Journal of petroleum and environment Biotechnology.p1-9

Behari Pradeep, Singh J.B and Yadava R.B (2003).Crop coefficients and evapotranspiration of berseem (Trifoliuma lexandarium L) grown under semi arid conditions. Journal of agrometeorology.5 (2):p53-57

Bhandari, S.G. and Shaha, S.K. 1995. Estimation of potential evapotranspiration using a single weather element. The evaporation. Mausam. 46 (2):p 141-148.

Bhatnagar, V.K. and Kundu, S. 1990. Evapotranspiration demand and pattern of soil moisture extraction of four rainfed winter crops in mid-hills of Uttar Pradesh. Indian Journal of Agricultural Science. 60 (11): p767769.

De melo Giovani L, TFernandes Andrel (2010). Evaluation of empirical methods to estimate reference evapotranspiration in uberera, state of minas, Brazil. Journal of agricultural 
engineering.p875-885

Ding, D.F. and Zhang, X.H. 1994. A preliminary study of the water requirement of major crops in the Huaibei area of Jiangsu Province. Ziranziyuan. No(3):p 40-46.
Doorenbos, J. and Pruitt, W.O. 1977. Guidelines for predicting crop water requirement. Irrigation and Drainage paper 24 (rev, 1977). F.A.O., Rome, p. 144.

\section{How to cite this article:}

Usha Durgam and Sastri, A.S.R.A.S. 2018. Comparison of the PET Values with the Open Pan Evaporation and Computation of Crop Coefficients. Int.J.Curr.Microbiol.App.Sci. 7(07): 12981306. doi: https://doi.org/10.20546/ijcmas.2018.707.155 